кандидат педагогічних наук, доцент

(Мелітопольський державний педагогічний університет імені Богдана Хмельницького) okp@mdpu.org.ua

ORCID: 0000-0003-0653-6423

\title{
ПРОБЛЕМА ПРОФЕСІЙНОЇ ПІДГОТОВКИ МАЙБУТНІХ УЧИТЕЛІВ ДО ТЬЮТОРСЬКОЇ ДІЯЛЬНОСТІ У ПЕДАГОГІЧНІЙ ТЕОРІї
}

Стаття присвячена аналізу українських наукових досліджень з проблеми професійної підготовки майбутніх учителів до тьюторської діяльності. Автором класифіковано наукові дослідження щзодо професійної підготовки майбутніх учителів до тьюторської діяльності за шістьма напрямами: фундаментальні праці з основ історії та теорії педагогічної освіти і педагогічної діяльності; праці, у яких висвітлені сучасні освітні парадигми, конщепщії, методологічні підходи до професійної підготовки майбутніх учителів; праці про сутність тьюторства, тьюторського супроводу та тьюторської діяльності; прачі, які присвячені проблемі професійної підготовки майбутніх учителів до тьюторської діяльності; праці, щуо висвітлюють питання формування тьюторської компетентності майбутніх учителів; праці, щуо розкривають діяльність учителя з індивідуалізації навчання. Подано короткий аналіз кожного напряму.

Ключові слова: тьюторська діяльність, професійна підготовка, наукові дослідження, педагогічна теорія.

Постановка проблеми. Проблема професійної підготовки майбутніх учителів до тьюторської діяльності вимагає розгляду широкого кола питань: починаючи від формування уявлення про тьюторську діяльність до аналізу та пропозиції ефективних підходів до професійної підготовки майбутніх учителів до здійснення функцій тьютора.

Вирішення проблеми ефективної професійної підготовки майбутніх учителів до тьюторської діяльності та ії подальші перспективи значною мірою залежать від грунтовного вивчення накопиченого педагогічного досвіду 3 цієї проблематики. Проаналізуємо вітчизняні дослідження 3 проблеми професійної підготовки майбутніх учителів до тьюторської діяльності. Роботи зарубіжних авторів, які висвітлюють особливості такої підготовки в зарубіжних країнах будуть розглянуті у третьому розділі дослідження.

Аналіз останніх досліджень і публікацій. У сучасних науково-педагогічних дослідженнях вченими здійснюються спроби класифікувати праці з окремих аспектів підготовки майбутніх учителів (Г. Т. Кловак, Н. А. Овчаренко, Ю. Д. Шаповал ), зокрема щодо підготовки до тьюторської діяльності (М. В. Іващенко, Т. І. Койчева, А. К. Сучану). Проте цілісного аналізу наукових та науково-методичних праць 3 проблеми професійної підготовки майбутніх учителів до тьюторської діяльності не було проведено.

Метою статті $є$ здійснення аналізу вітчизняних наукових досліджень 3 проблеми професійної підготовки майбутніх учителів до тьюторської діяльності.

Виклад основного матеріалу дослідження. Особливого значення, у дослідженні означеної проблеми набуває питання класифікації наукових досліджень щодо професійної підготовки майбутніх учителів до тьюторсьокї діяльності. Для цього нами було здійснено цілісне дослідження наукової вітчизняної думки, у результаті чого ми можемо класифікувати наукові роботи з обраної проблеми за такими напрямами:

1) фундаментальні праці, у яких розкриті загальні основи історії та теорії педагогічної освіти $\mathrm{i}$ педагогічної діяльності;

2) праці, у яких висвітлені сучасні освітні парадигми, концепції, методологічні підходи професійної підготовки майбутніх учителів;

3) праці, у яких розглянуто сутність тьюторства, тьюторського супроводу та тьюторської діяльності;

4) праці, які присвячені проблемі професійної підготовки майбутніх до тьюторської діяльності, зокрема у дистанційному навчанні;

5) праці, що висвітлюють питання формування тьюторської компетентності майбутніх учителів;

6) праці, що розкривають діяльність учителя з індивідуалізації навчання учнів загальноосвітньої школи.

До першого напряму дослідження педагогічного досвіду ми віднесли дослідження і фундаментальні праці, у яких розкриті загальні основи історії та теорії педагогічної освіти і педагогічної діяльності.

Дослідження та праці таких науковців як Т. М. Десятов, І. А. Зязюн, Г. Т. Кловак, Т. С. Кристопчук, В. А. Семиченко, С. О. Сисоєва, А. В. Сущенко, В. Д. Федоров дали ключ до розуміння багатьох явищ у педагогічній освіті та сприяли поглибленню і цілісності вирішення означеної проблеми. Сутності педагогічної майстерності як основі педагогічної діяльності присвячені праці I. А. Зязюна та 
С. О. Сисоєвої. Грунтовно досліджуючи теоретико-методологічні основи базової педагогічної освіти майбутніх учителів, В. І. Шахов подає основні вимоги до базової педагогічної освіти: вища педагогічна освіта повинна сприяти становленню фахівця-професіонала, морально зрілої, відповідальної особистості, спроможної до виконання інваріантних загальнопедагогічних функцій (дидактичної, виховної, комунікативної, організаторської, діагностичної, інформаційної), безупинного розвитку та самореалізації в професійній діяльності [1: 399-403].

Висвітлюючи психологічний аспект педагогічної діяльності В. А. Семиченко, наголошує, що цільова педагогічна діяльність спрямована передусім на іншу людину і "... має сенс лише тоді, коли в особистості його учня, вихованця акумулюються той науковий і соціальний досвід, який має бути переданий педагогом", і "тільки те, що втілюється, інтегрується у внутрішній світ конкретних учнів, має сенс і визначає цінність педагогічної діяльності" [2: 301]. Досліджуючи теоретико-методичні основи гуманізації педагогічної діяльності вчителя в основній школі, А. В. Сущенко [3] доводить, що необхідними й достатніми умовами набуття вчителем досвіду педагогічної діяльності на засадах гуманізму є сформована особистісна потреба у самореалізації гуманістичних потенцій в обраній професії, постійне підвищення фахової майстерності, усвідомлена відмова від використання формальних ролей, щире прийняття та співпереживання іншій людині, інтерактивна інтелектуальна співтворчість та діалогова культура.

Аналіз наукових та навчально-методичних праць показав достатнє висвітлення основних питань та загальних основ історії та теорії педагогічної освіти і педагогічної діяльності. Сучасним науковим дослідженням за таким напрямом притаманно: вивчення та висвітлення різних історичних періодів становлення національної педагогічної освіти, пошук нових теорій удосконалення педагогічної освіти та якості педагогічної діяльності, зокрема в аспектах педагогічного професіоналізму та майстерності, психології педагогічної діяльності.

Другим напрямом дослідження професійної підготовки майбутніх учителів до тюторської діяльності $є$ праці, у яких висвітлені сучасні освітні парадигми, концепції, методологічні підходи та технології їх професійної підготовки. У сучасних наукових дослідженнях знаходять відображення методологічні та методичні засади професійної підготовки майбутніх учителів, що сприяє поглибленню і цілісності вирішення проблеми дослідження, як приклад, праці таких науковців як С. С. Барбіна, І. М. Богданова, I. В. Гавриш, Н. В. Гузій та ін.. Так, І. В. Гавриш констатує такі суттєві зміни у методології безперервної педагогічної освіти: традиційна знаннєва парадигма підготовки освітянських кадрів, на якій грунтувалася радянська педагогічна наука, поступається місцем особистісно-орієнтованій інноваційній парадигмі [4: 1].

Концепцію педагогічного професіоналізму обгрунтовує у своєму дослідженні Н. В. Гузій, зазначаючи, що іiі ключова ідея полягає у створенні дидаскалогічно-орієнтованого (від дидаскалогія галузі теоретичних i прикладних психолого-педагогічних знань про сутність, особливості, закономірності, принципи, механізми успішного функціонування фахівця у педагогічній професії) педагогічного простору, який сприяв би успішному самовизначенню студентів щодо соціальнокультурних цінностей і смислів педагогічної професії, - від усвідомлення правильності ії вибору через цілеспрямований розвиток професійних інтересів і схильностей, вироблення системи поглядів, переконань, установок, до набуття теоретичного та практичного досвіду професійно-творчого зростання та самореалізації у педагогічній професії, а відтак, і становлення їх професіоналізму [5: 385].

Методологічні функції педагогічної майстерності в системі підготовки вчителя як фактора 屰 інтеграції глибоко розкриті в концепції Є. С. Барбіної [6]. За твердженнями автора, завдяки педагогічній майстерності у процес професійної підготовки в наочній формі імпліцитно вноситься парадигматичний підхід сучасної наукової методології: робота зі складними структурними об'єктами, ознайомлення 3 системними властивостями цих об’єктів, формування елементів системного мислення стосовно до педагогічних об'єктів.

Компетентнісний підхід у професійній підготовці майбутніх учителів набув розвитку у роботах Н. А. Глузман, В. Ф. Заболотного, Л. С. Петухової, О. В. Шестопалюка та ін.. Інші підходи розглянуто у дослідженні В. Ю. Ковальчука, а саме: науковець пропонує підходи до модернізації професійної та світоглядно-методологічної підготовки сучасного вчителя в їх взаємозв'язку з потребами суспільства у реформуванні середньої освіти. Як такі, він виділяє системний, структурнофункціональний, синергетичний і діяльнісний підходи. Крім того, одним із вирішальних підходів у професійній підготовці учителя науковець вважає цілеспрямоване здійснення національносвітоглядної орієнтації, оскільки сучасний світ став світом націй, національних міжнародних відносин, національна освіта стає наріжною для людської цивілізації початку ХХІ ст. [7: 256]. На системному підході до професійної підготовки майбутніх учителів акцентує увагу низка науковців: Л. В. Коваль, М. Г. Криловець, С. М. Мартиненко, Н.В.Морзе, В. В. Осадчий, О. М. Семеног, О. І. Шапран та ін.

У цілому, незважаючи на те, що питання освітніх парадигм, концепцій, підходів та технологій 
педагогічної освіти постійно знаходяться у полі зору сучасних дослідників, методологічні засади професійної підготовки майбутніх учителів до тьюторської діяльності є недостатньо висвітленими у наукових працях.

До третього напряму вивчення наукового досвіду ми відносимо праці, в яких висвітлюється сутність тьюторства, тьюторського супроводу та тьюторської діяльності з дітьми шкільного віку, зокрема в умовах дистанційного навчання. Слід зазначити, що у вітчизняній науково-педагогічній думці не достатньо грунтовних праць щодо зазначеної тематики, проте наявні окремі розвідки вчених та педагогів-практиків, серед яких А. М. Бойко, С. В. Вєтров, О. В. Руденко, О. М. Троїцька, Л. О. Шеїна та iн.

На думку А. М. Бойко, актуальність тьюторства сьогодні зумовлена, по-перше, тим, що тьюторська технологія спрямована на задоволення освітніх потреб особистості, країни і суспільства, їх гармонізації; по-друге, вона наочно демонструє залежність розвитку країни від результатів освіти окремих індивідів і спрямована на їх піднесення; по-третє, визначається необхідністю особистісно-орієнтованої, гуманної педагогічної взаємодії; по-четверте, у зв'язку з цим персоніфікацією педагогічної освіти, побудовою власної програми, яка здійснюється за індивідуальними можливостями; по-п’яте, потребою формування суб'єкт-суб'єктних толерантних відносин учасників педагогічного процесу, що супроводжують особистісно-професійний розвиток майбутніх педагогів. Думаю, зрозуміло, що у зв’язку зі зменшенням контингенту студентів та й учнів тьюторство буде проявлятися все більш реально і затребувано [8: 7].

У праці О. В. Руденко [9] акцентується увага на ролі тьютора у дистанційному навчанні. Автор у ролі тьютора бачить людину, яка супроводжує та підтримує процес самоосвіти, здійснює підтримку розробки та реалізації індивідуальних освітніх проектів і програм, його компетенції, функціонал та обов’язки. Вважаючи тьюторство культурою, що сформувалася в історії паралельно культурі викладання i навчання, О. В. Руденко підкреслює думку, що тьюторство затребуване в сферах досить складного змісту, де немає однозначних методів пізнання, де розуміння вимагає персональних, особистих зусиль як у математиці. Тобто автор звужує розуміння тьюторства до функцій репетитора, який навчає певному предмету, що не узгоджується із думкою С. В. Вєтрова, який позиціонує тьютора як педагога, який допомагає в складанні індивідуальної освітньої програми, здійснює ії супровід, грає роль навігатора в просуванні вздовж індивідуальної освітньої траєкторії (маршруту) [10: 63]. Л. О. Шеїна також більш розширеною вбачає сутність діяльності тьютора, зазначаючи, що сучасне тьюторство більший акцент робить на адаптацію до соціуму і саморозвиток індивіда у різноманітних напрямках. На їі думку, тьютор $\epsilon$ більш конкретизованим агентом соціалізації, здійснюючи процес соціальної практики - особливий тип гуманітарного педагогічного супроводу процесу індивідуалізації. Як і С. В. Вєтров авторка робить акцент у тьюторській діяльності на реалізацію індивідуальної освітньої програми і прогнозування професійної та життєвої траєкторії тьюторанта [11: 233].

Аналізуючи явище тьюторського супроводу учнів як нової форми гуманістичного навчання, Р. А. Полєшко та В. В. Щорс [12] акцентують увагу на діяльності тьютора в умовах дистанційного навчання. Дослідники вважають, що тьютор - це вчитель-консультант, який організовує навчальний процес за дистанційною формою й виконує одночасно функції вчителя, консультанта й організатора навчального процесу. Разом із тим науковці слушно зазначають, що тьютор має інший світогляд: замість прагнення до уніфікації він націлений на збереження та культивування різноманітності, підтримку та розвиток індивідуальності, вивчення індивідуального стилю навчально-пізнавальної діяльності кожного учня й надання йому адресної допомоги в подоланні тих чи інших проблем.

Сенс тьюторства в подоланні антропологічного дефіциту в освіті вбачає О. П. Літовка [13]. Автор зазначає, що цей дефіцит створює брак "особистої присутності" людини в освіті, брак особистого й освітнього сенсу, брак відповідальності людини за свою освіту. У зв’язку із цим, на її думку, тьюторство передбачає формування у вчителя творчих компетентностей, готовності до перенавчання, уміння навчатися протягом усього життя, вибирати і оновлювати професійний шлях.

Отже, у розглянутих наукових працях, які аналізують сутність тьюторства, тьюторського супроводу та тьюторської діяльності з дітьми шкільного віку, здійснюється пошукова робота щодо осягнення окреслених понять і явищ, проте цілісних та грунтовних досліджень 3 теорії тьюторства та тьюторської діяльності у вітчизняній педагогічній теорії не достатньо.

Четвертий напрям вивчення наукової емпірії щодо досліджуваної проблеми складають праці, присвячені професійній підготовці майбутніх учителів до тьюторської діяльності, зокрема у дистанційному навчанні (М. В. Іващенко, Т. І. Койчева, А. К. Сучану та ін.). Проблема тьюторства для вітчизняної науки на відміну від зарубіжної педагогіки є досить новою, i, не зважаючи на те, що науковцями ведуться активні наукові дослідження, вона ще не знайшла достатнього висвітлення.

А. К. Сучану досліджуючи феномен підготовки майбутніх педагогів до тьюторської діяльності наголошує, що вона повинна проектувати освітнє та навальне середовище із залученням сучасних інформаційних, комп'ютерних і педагогічних технологій; включати як традиційні методи i форми навчання студентів, так і методи і форми навчання, характерні для європейської зони вищої освіти; 
забезпечувати розвиток мобільності; враховувати основні положення та взаємозв'язки теорій діяльності й особистості; сприяти особистісно-професійному розвитку й саморозвитку; включати теоретичну і практичну підготовку до педагогічної, науково-дослідної, творчої, різновидів пошукової діяльності, що зумовлює оволодіння уміннями оперувати результатами власної дослідницької роботи [14: 43]. Проте дослідниця зупиняється лише на професійній підготовці педагогів на рівні магістратури і тільки гуманітарних спеціальностей, не торкаючись проблеми професійної підготовки майбутніх учителів до тьюторської діяльності на рівні бакалавра. Такий підхід зумовлений більшою варіативністю навчальних програм магістерських спеціальностей, що дозволяє здійснювати професійну підготовку педагогів до тьюторської діяльності не зважаючи на відсутність такої спеціальності у переліку галузей знань і спеціальностей, за якими здійснюється підготовка здобувачів вищої освіти.

Т. І. Койчева розглядала у своєму дисертаційному дослідженні аспекти підготовка майбутніх учителів гуманітарних спеціальностей як тьюторів для системи дистанційної освіти. Дослідницею було запропоновано зміст теоретичної і практичної підготовки майбутніх учителів-гуманітаріїв, що забезпечує їхню професійно-педагогічну готовність до виконання тьюторських функцій у системі дистанційної освіти, та методику поетапної підготовки вчителя-гуманітарія до виконання тьюторських функцій у системі дистанційної освіти відповідно до структури чинних навчальних планів. У цілях нашого дослідження цінним є запропонований авторкою зміст підготовки майбутніх учителів гуманітарних спеціальностей до виконання функцій тьютора в системі дистанційного навчання, який відповідно до обсягу визначених знань і вмінь, що дозволяють виконувати вчителю функції тьютора в системі дистанційної освіти, авторка базує на вивченні студентами курсу "Інформатика" та спецкурсу "Методика роботи тьютора в системі дистанційної освіти" [15: 13-14].

Аналіз праць за цим напрямом відобразив наявність грунтовних досліджень проблем професійної підготовки майбутніх учителів до тьюторсьокї діяльності та недостатнє залишаються не достатньо висвітленими питання розробки концепції та моделі професійної підготовки до тьюторської діяльності майбутніх учителів, зокрема, що грунтуються на засадах компетентнісного, праксеологічного антропоцентричного та студентоцентричного підходів.

До n'ятого напряму віднесено праці, спрямовані на формування тьюторської компетентності майбутніх учителів (Т. Пахомова, М. В. Іващенко) серед яких також спостерігається не достатня кількість грунтованих досліджень. Досліджуючи формування готовності студентів вищих педагогічних навчальних закладів до діяльності тьютора М. В. Іващенко [16] зазначає, що очікування та вимоги до тьюторів, що задаються сучасною системою освіти передбачають певний достатній рівень професійної компетентності, що включає в себе: професійні знання, вміння та навички виконання діяльності, особистісні здібності щодо діяльності в широкому аспекті, налаштованість та бажання їі виконувати. Автор вважає, що тьютор має володіти професійною педагогічною компетентністю, компетентність у сфері андрагогіки, інформаційною компетентністю, а також не менш видатними комунікативними (уміння створювати мотивацію, вирішувати конфлікти, розвивати співпрацю на основі знання психології міжособистісних стосунків, психології великих і малих груп, вікової психології) i психологопедагогічними (уміння підбирати і розробляти навчально-методичні матеріали, оцінювати їх якість 3 погляду сучасних норм; використовувати в процесі тьюторської діяльності сучасні педагогічні технології) уміннями.

Підсумовуючи аналіз праць з цього напряму, слід зазначити, що науковцями достатньо висвітлені питання сутності та засобів формування тьюторської компетентності у вищих навчальних закладах (С. О. Сисоєва, В. В. Осадчий [17]), в умовах дистанційного навчання (В. М. Кухаренко, О. В. Лось) та післядипломної освіти (Ю.С. Присяжнюк). Натомість тьюторській компетентності майбутніх учителів приділено не достатньо уваги у вітчизняних психолого-педагогічних дослідженнях.

До шостого напряму віднесено праці, що розкривають діяльність учителя з індивідуалізації навчання учнів загальноосвітньої школи. У дослідженнях С. Ю. Ніколаєва, В. О. Онищука, О. Я. Савченко, питання урахування індивідуальних особливостей учня під час навчання позиціонуються як основа індивідуалізації навчання. Науковці О. А. Жерновникова, С. Г. Литвинова, розглядають індивідуалізацію навчання як наближення навчального процесу школи до оптимальної моделі навчання учня. Зокрема, О.Я. Савченко зазначаючи, що професійний обов'язок учителя - бачити, насамперед, особистість конкретної дитини, якомога точніше визначати ії пізнавальні здібності, а потім обирати відповідний засіб впливу, вважає врахування індивідуальних особливостей першою засадою реалізації принципу індивідуалізації і диференціації навчання. Проте вона розглядає ці принципи у рамках шкільного навчання, вважаючи, що принцип індивідуалізації навчання реалізується переважно через систему диференційованих завдань, залежно від рівнів підготовки учнів у процесі спілкування 3 дітьми, стимулювання їх, оцінювання результатів праці [18: 88].

Такий підхід не сумісний в умовах додаткового або сімейного навчання, які ми вважаємо полем діяльності тьютора, де індивідуалізація полягає у наданні дитині можливості участі у різноманітній освітній діяльності відповідно до індивідуальних освітніх потреб і запитів, в обгрунтуванні напрямів 
здійснення освітньої індивідуальної програми, у виборі і проходженні індивідуального освітнього маршруту у тісній співпраці з учителем.

Компромісний варіант пропонує О.А. Жерновникова [19]: у навчальних закладах нового типу надавати можливості особливо обдарованим учням спільно з учителем розробляти індивідуальні навчальні програми з окремих дисциплін. У такому разі учні, об'єднані спільним інтересом до одного навчального предмета, грунтуючись на міжпредметних зв'язках, отримують можливість вивчати певні теми в індивідуальному темпі, використовуючи потенціал основної та додаткової освіти в межах школи.

Отже, у наукових працях за таким напрямом висвітлюються питання індивідуалізації навчання учнів загальноосвітньої школи, що $є$ підгрунтям для тьюторської діяльності; розглядаються рівні ії розвитку та види; обгрунтовуються методики та технології впровадження індивідуалізації у школі.

Висновки 3 дослідження та перспективи. Таким чином, здійснений аналіз наукових та науковометодичних праць надав можливість дійти висновку про недостатню дослідженість проблеми професійної підготовки майбутніх учителів до тьюторської діяльності у вітчизняній науковій думці.

Перспективами подальших розвідок є обгрунтування структури тьюторської діяльності, концепції та моделі професійної підготовки майбутніх учителів до тьюторської діяльності.

\section{СПИСОК ВИКОРИСТАНИХ ДЖЕРЕЛ ТА ЛІТЕРАТУРИ}

1. Шахов В. І. Теоретико-методологічні основи базової педагогічної освіти майбутніх учителів : дис... доктора пед. наук : 13.00.04 / Володимир Іванович Шахов. - Вінниця, 2008. - 532 с.

2. Семиченко В. А. Психологія педагогічної діяльності : [навч. посіб.] / В. А. Семиченко - К. : Вища шк., 2004. $-335 \mathrm{c}$.

3. Сущенко А. В. Теоретико-методичні основи гуманізації педагогічної діяльності вчителя в основній школі : дис... доктора пед. наук : 13.00.04 / Андрій Віталійович Сущенко. - Запоріжжя, 2003. - 422 с.

4. Гавриш І. В. Теоретико-методологічні основи формування готовності майбутніх учителів до інноваційної професійної діяльності : автореф. дис. на здобуття наук. ступеня доктора пед. наук : спец. 13.00.04 "Теорія та методика професійної освіти" / Ірина Володимирівна Гавриш. - Луганськ, 2006. - 44 с.

5. Гузій Н. В. Категорія професіоналізму в теорії і практиці підготовки майбутнього педагога : дис... доктора пед. наук : 13.00.04 / Наталія Василівна Гузій. - К., 2007. - 577 с.

6. Барбіна Є. Роль і функції педагогічної майстерності у системі професійної підготовки педагогічних кадрів / Є. Барбіна // Педагогіка і психологія професійної освіти. - 2001. - № 1. - С. 26-34.

7. Ковальчук В. Ю. Модернізація професійної та світоглядно-методологічної підготовки сучасного вчителя : дис... доктора пед. наук : 13.00.04 / Володимир Юльянович Ковальчук. - К., 2005. - 406 с.

8. Бойко А. М. Тьютор - якісно вища педагогічна позиція і новий простір духовно-моральної взаємодії / А. М. Бойко // Педагогічні науки : [збірник наукових праць]. - Полтава, 2011. - С. 4-10.

9. Руденко О. В. Математика - дистанційно. Тьюторство / О.В. Руденко. - К. : Редакції газет природничоматематичного циклу, 2012. - $117 \mathrm{c.}$

10. Ветров С. В. Тьюторство как средство построения индивидуальной образовательной программы/ С. В. Ветров // Проблемы современного педагогического образования. - 2015. - С. 59-66.

11. Шеїна Л. О. Тьюторство як комплексний соціальний психолого-педагогічний феномен / Л. О. Шеїна // Вісник Луганського національного університету імені Тараса Шевченка. Педагогічні науки. - 2014. - № 4. C. 231-238.

12. Полєшко Р. А. Тьюторський супровід учнів як нова форма гуманістичного навчання / Р. А. Полєшко, В. В. Щорс // Управління школою. - № 22-24 (322-324) серпень 2011 р. - С. 42-44.

13. Літовка О. П. Тьюторство як професійно-педагогічна позиція майбутнього вчителя / О. П. Літовка // Сучасні педагогічні технології підготовки майбутніх учителів в умовах ступеневої освіти : матеріали регіон. наук.практ. конф. - Стаханов, 2013. - С. 202-208.

14. Сучану А. К. Формування ціннісно-смислової готовності до тьюторської діяльності у магістрів гуманітарних спеціальностей : дис... канд. пед. наук : 13.00.04 / Ася Костянтинівна Сучану. - Кіровоград, 2016. - 266 с.

15. Койчева Т. І. Підготовка майбутніх учителів гуманітарних спеціальностей як тьюторів для системи дистанційної освіти : автореф. дис. на здобуття наук. ступеня канд. пед. наук : спец. 13.00.04 "Теорія та методика професійної освіти" / Тетяна Іванівна Койчева. - О., 2004. - 20 с.

16. Іващенко М. В. Мультимедійні засоби формування компетентності майбутнього тьютора / М. В. Іващенко // Педагогічні науки: теорія, історія, інноваційні технології: науковий журнал Сумського державного педагогічного університету ім. А. С. Макаренка. - 2009. - № 1. - С. 203-210.

17. Сисоєва С. О. Професійна підготовка викладача-тьютора: теорія і методика: [навч.-метод. посіб.]/ С. О. Сисоєва, В. В. Осадчий, К. П. Осадча. - Київ, Мелітополь : ТОВ "Видавничий будинок ММд", 2011. $280 \mathrm{c}$.

18. Савченко О. Я. Умій вчитися / О. Я. Савченко. - К. : Освіта, 1996. - 192 с.

19. Жерновникова О. А. Становлення та розвиток ідеї індивідуалізації навчання старшокласників у навчальних закладах нового типу/ О.А. Жерновникова// Педагогіка формування творчої особистості у вищій i загальноосвітній школах. - 2015. - Вип. 42. - С. 459-467. 


\section{REFERENCES (TRASLATED \& TRANSLITERATED)}

1. Shakhov V. I. Teoretyko-metodolohichni osnovy bazovoi pedahohichnoi osvity maibutnikh uchyteliv [Theoretical and Methodological Foundations of the Basic Pedagogical Education of Future Teachers] : dys... doktora ped. nauk : 13.00.04 / Volodymyr Ivanovych Shakhov. - Vinnytsia, 2008. - $532 \mathrm{s.}$

2. Semychenko V. A. Psykholohiia pedahohichnoi diial'nosti [Psychology of Pedagogical activity] : [navch. posib.]/ V. A. Semychenko - K. : Vyshcha shk., 2004. - 335 s.

3. Sushchenko A. V. Teoretyko-metodychni osnovy humanizatsii pedahohichnoi diial'nosti vchytelia $\mathrm{v}$ osnovnii shkoli [Theoretical and Methodological Foundations of Humanization of Teacher's Activity in a Primary School] : dys... doktora ped. nauk : 13.00.04 / Andrii Vitaliiovych Sushchenko. - Zaporizhzhia, 2003. - $422 \mathrm{~s}$.

4. Havrysh I. V. Teoretyko-metodolohichni osnovy formuvannia hotovnosti maibutnikh uchyteliv do innovatsiinoi profesiinoi diial'nosti [Theoretical and Methodological Foundations of Forming the Readiness of Future Teachers for Innovative Professional Activities] : avtoref. dys. na zdobuttia nauk. stupenia doktora ped. nauk : spets. 13.00.04 "Teoriia ta metodyka profesiinoi osvity" / Iryna Volodymyrivna Havrysh. - Luhansk, 2006. - $44 \mathrm{~s}$.

5. Huzii N. V. Katehoriia profesionalizmu v teorii i praktytsi pidhotovky maibutnoho pedahoha [The Category of Professionalism in the Theory and Practice of Preparing a Future Teacher] : dys... doktora ped. nauk : 13.00 .04 / Nataliia Vasylivna Huzii. - K., 2007. - 577 s.

6. Barbina E. Rol' i funktsii pedahohichnoi maisternosti u systemi profesiinoi pidhotovky pedahohichnykh kadriv [The Role and Functions of Pedagogical Skills in the System of Professional Training of Pedagogical Personnel]/ E. Barbina // Pedahohika i psykholohiia profesiinoi osvity [Pedagogy and Psychology of Professional Education]. 2001. - № 1. - S. 26-34.

7. Kovalchuk V. U. Modernizatsiia profesiinoi ta svitohliadno-metodolohichnoi pidhotovky suchasnoho vchytelia [Modernization of Professional and Philosophical and Methodological Training of a Modern Teacher] : dys... doktora ped. nauk : 13.00.04 / Volodymyr Yulianovych Kovalchuk. - K., 2005. - 406 s.

8. Boiko A. M. Tiutor - yakisno vyshcha pedahohichna pozytsiia i novyi prostir dukhovno-moral'noi vzaiemodii [Tutor - a Higher Quality Pedagogical Position and a New Space of Spiritually-Moral Co-operation]/ A. M. Boiko // Pedahohichni nauky [Pedagogical Sciences] : zbirnyk naukovykh prats'. - Poltava, 2011. - S. 4-10.

9. Rudenko O. V. Matematyka - dystantsiino. Tiutorstvo [Mathematics Remotely. Tutoring] / O. V. Rudenko. - K. : Redaktsii hazet pryrodnycho-matematychnoho tsyklu, 2012. - $117 \mathrm{~s}$.

10. Vetrov S. V. Tiutorstvo kak sredstvo postroeniia indyvydual'noi obrazovatel'noi prohrammy [Tutoring as a Means of Building an Individual Educational Program]/ S. V. Vetrov// Problemy sovremennoho pedahohycheskoho obrazovaniia [Problems of Modern Pedagogical Education]. - 2015. - S. 59-66.

11. Sheina L. O. Tiutorstvo yak kompleksnyi sotsial'nyi psykholoho-pedahohichnyi fenomen [Tutoring as a Complex Social Psychological and Pedagogical Phenomenon]/ L. O. Sheina// Visnyk Luhanskoho natsional'noho universytetu imeni Tarasa Shevchenka. Pedahohichni nauky [Journal of Lugansk Taras Shevchenko National University. Pedagogical Sciences]. - 2014. - № 4. - S. 231-238.

12. Polieshko R. A. Tiutorskyi suprovid uchniv yak nova forma humanistychnoho navchannia [Teutor Accompaniment of Students as a New Form of Humanistic Learning]/ R. A. Polieshko, V. V. Shchors // Upravlinnia shkoloiu [School Management]. - № 22-24 (322-324) serpen' 2011 r. - S. 42-44.

13. Litovka O. P. Tiutorstvo yak profesiino-pedahohichna pozytsiia maibutnoho vchytelia [Teaching as a Vocational and Pedagogical Position of the Future Teacher] / O. P. Litovka // Suchasni pedahohichni tekhnolohii pidhotovky maibutnikh uchyteliv $\mathrm{v}$ umovakh stupenevoi osvity [Modern Pedagogical Technologies of future teachers' preparation in conditions of graduate education] : materialy rehion. nauk.-prakt. konf. - Stakhanov : DZ "LNU imeni Tarasa Shevchenka", 2013. - S. 202-208.

14. Suchanu A. K. Formuvannia tsinnisno-smyslovoi hotovnosti do tiutorskoi diial'nosti u mahistriv humanitarnykh spetsial'nostei [Formation of Value-Semantic Readiness for Tutor Activity at the Masters of the Humanities] : dys... kand. ped. nauk : 13.00.04 / Asia Kostiantynivna Suchanu. - Kirovohrad, 2016. - 266 s.

15. Koicheva T. I. Pidhotovka maibutnikh uchyteliv humanitarnykh spetsial'nostei yak tiutoriv dlia systemy dystantsiinoi osvity [Future Humanities Teachers' Training as Tutors of Distance Learning Systems] : avtoref. dys. na zdobuttia nauk. stupenia kand. ped. nauk : spets. 13.00.04 "Teoriia ta metodyka profesiinoi osvity" / Tetiana Ivanivna Koicheva. - O., 2004. - 20 s.

16. Ivashchenko M. V. Multymediini zasoby formuvannia kompetentnosti maibutnoho tiutora [Multimedia Means of Forming the Competence of the Future Tutor]/ M.V. Ivashchenko// Pedahohichni nauky: teoriia, istoriia, innovatsiini tekhnolohii [Pedagogical Sciences: Theory, History, Innovative Technologies] : naukovyi zhurnal Sumskoho derzhavnoho pedahohichnoho universytetu im. A. S. Makarenka. - 2009. - № 1. - S. 203-210.

17. Sysoieva S. O. Profesiina pidhotovka vykladacha-tiutora [Professional Training of a Teacher-Tutor]: teoriia i metodyka : [navch.-metod. posib.] / S. O. Sysoieva, V. V. Osadchyi, K. P. Osadcha. - Kyiv, Melitopol' : TOV "Vydavnychyi budynok MMD", 2011. - $280 \mathrm{~s}$.

18. Savchenko O. Ya. Umii vchytysia [Be Able to Study] / O. Ya. Savchenko. - K. : Osvita, 1996. - 192 s.

19. Zhernovnykova O. A. Stanovlennia ta rozvytok idei indyvidualizatsii navchannia starshoklasnykiv u navchalnykh zakladakh novoho typu [Formation and Development of the Idea of Individualization of Training of Senior Pupils in the Schools of a New Type]/ O. A. Zhernovnykova// Pedahohika formuvannia tvorchoi osobystosti u vyshchii i zahalnoosvitnii shkolakh [Pedagogy of Formation of a Creative Person in Higher and Secondary Schools]. - 2015. Vyp. 42. - S. 459-467. 


\section{Осадчая К. П. Проблема профессиональной подготовки будущихх учителей к тьюторской деятельности в педагогической теории.}

Статья посвящена анализу украинских научных исследований по проблеме профессиональной подготовки будущих учителей к тьюторской деятельности. Автором классифицировань научнье исследования о профессиональной подготовке будущих учителей к тьюторской деятельности по шести направлениям: фундаментальные труды по основам истории и теории педагогического образования и педагогической деятельности; труды, в которых освещены современные образовательные парадигмы, кониепции, методологические подходы к профессиональной подготовке будущих учителей; труды о

сущиноти тьюторства, тьюторского сопровождения и тьюторской деятельности; работь, посвященные проблеме профессиональной подготовки будущих учителей к тьюторской деятельности; труды, освещзающие вопросы формирования тьюторской компетентности будущчих учителей; труды, раскрывающие деятельность учителя по индивидуализации обучения. Дан краткий анализ каждого направления.

Ключевые слова: тьюторская деятельность, профессиональная подготовка, научные исследования, педагогическая теория.

\section{Osadcha K. P. The Problem of Future Teachers' Professional Training for Tutor Activities in the Pedagogical Theory.}

The problem of future teachers training for tutor activities requires consideration of a wide range of issues: from forming the idea of a tutor activity to analysis and suggestion of efficient approaches to future teachers training for fulfilling tutor functions. Research of professional training of teachers for tutor activities requires a thorough study of accumulated teaching experience. The author analyses the Ukrainian scientific research papers concerning teachers training for tutor activities, classifying them into the six areas: fundamental works on the basics of history and theory of teacher education and educational activities; papers, which highlight the current educational paradigms, concepts, methodological approaches to training future teachers; papers about essence of tutoring, tutor support and tutor activities; works concerning the problem of future teachers training for tutor activities; works covering issues of forming tutor competence of future teachers; papers that reveal the teacher activities to implement learning individualization. The paper presents a brief analysis of each area. Particular

attention is paid to the analysis of scientific papers on the theory and practice of tutoring, including the description of tutor competence (S. O. Sysoieva, V.V. Osadchy, V. M. Kukharenko), the nature of tutoring, tutor support and tutor activities (A. M. Boyko, S. V. Vietrov, O. M. Troitska). The analysis of scientific and methodical papers made it possible to conclude that research of the problem of professional training of future teachers for tutor activities in Ukrainian scientific thought is insufficient. The issues of determination of the structure of tutor activities and development of concepts and models of future teachers for tutor activities are not highlighted reasonably.

Key words: tutor activities, training, research, educational theory. 